to that country as a source of supply at any cost for Germany of materials not found in sufficient quantities at home-materials to be obtained by force when trading methods failed.

That the United Kingdom experieneed similar difficulties is demonstrated by the detailed story of tariff-making as set out in the volume before us. What lessons can planners and reconstructors learn from this? Are they to assume that the tide will continue to flow in the direction it took in the 1900's and maintained so strongly in the 1930's? If so, then they ought to aim at what is called a 'balanced' agriculture, at production of high-quality goods by skilled craftsmen, at the development of small-scale rural industries, at wide diffusion of ownership of capital, land and houses, at anti-trust legislation and the like. But if they conclude that the trend has run its course (and there are some grounds for this belief) then public ownership and control of largescale industry with the State alone engaging in international trade might well be the policy to pursue. The choice is not an easy one to make. It is disquieting that the most vocal of the planners seem unaware that choosing is a necessary preliminary of action. J. G. SMITH.

\section{THE BIBLE EXAMINED}

\section{In Search of the Real Bible}

By A. D. Howell Smith. (Thinker's Library, No. 98.) Pp. v+120. (London: Watts and Co., Ltd., 1943.) 2s. net.

70 the question, What is the real Bible?, the 1 answer is that it resembles an ancient city site where many cultural strata exist one below the other. If the archæologist digs deeply, he will discover some very primitive remains, while nearer the surface lies more recent, and perhaps more advanced, material. Thus Mr. Howell Smith has no difficulty in unearthing some primitive and, to us, unpleasing elements in the Bible-deceptions, obscenities, and barbarities of various kinds. This should shock none but the Fundamentalist, who cherishes a preconceived and untenable idea about the Bible; the well-informed man knows that all primitive literatures display parallel traits. It is equally easy to show that the biblical cosmology and science are no longer tenable; though it would be an error to imagine that only one cosmology exists in the Bible. Of the Deity, varying conceptions are present in the Bible, as Mr. Howell Smith shows, and as one would expect from this fairly complete record of a development of religious ideas, which is what the Bible is.

Mr. Howell Smith supplies the reader with a clear and quite fair summary of the results of what is known as the Higher Criticism. He is inclined to overstress the divergences of opinion among scholars, who are pretty well agreed as to "the approximate dating, mode of composition, and historical value of the different books". Only the mentally indolent will be "bewildered" or reduced to believing "that perhaps the Fundamentalists are right in dismissing all biblical criticism as a mass of arbitrary speculations". For this reason it is to bo regretted that Mr. Howell Smith did not include a brief description of the methods of the biblical eritics, which are indeed very simple. There is nothing abstruse or recondite about them.

Mr. Howell Smith pays tribute to the high cultural value of some parts of the Bible. "The Canon of the Hebrew Prophets contains some of the most exalted literature mankind has produced, and many of its pages are afire with hatred of oppression and injustice". Job is "one of the greatest literary achievements in the world". Ruth is "a charming tale of loyalty and kindness". Jonth teaches "lessons of mercy and forgiveness". With regard to the last book, it might have been added that here alone in the Bible is displayed a delicate sense of humour.

Not the least interesting chapter of the book, "The Spade and the Critic", discusses the bearing of recent archæological discovery on the historicity of the events recorded in the Bible, and upon our knowledge as to the sources whence certain biblical ideas were derived. Perhaps most students will agree with Mr. Howell Smith that Sir Charles Marston's recent attempts to make the stones of Egypt and Mesopotamia refute the critics have not been very successful.

Of course one's estimate of the value of the Bible will depend very much upon the estimate one holds of the value of religion as an element in human culture. Mr. Howell Smith would not appear to place that value very high; and this necessarily involves a certain lack of sympathy with his subject. But apart from this defect, Mr. Howell Smith has written an informative little book.

\section{J. C. HaRDWICK.}

\section{AGRICULTURAL CROPS OF THE UNITED STATES}

\section{Field Crops}

By Prof. Howard C. Rather. (McGraw-Hill Publica* tions in the Agricultural Sciences.) Pp. ix +454. (New York : McGraw-Hill Book Co., Inc.; London: MeGraw-Hill Publishing Co., Ltd., 1942.) $26 s$.

THIS book sets out to describe the general principles underlying the cultivation of the principal agricultural crops 'grown in the United States, in a form suitable for first-year students in agricultural colleges. The book covers the principal American crops very evenly. It includes pasture and meadow management and the growing of leys and forage crops, particularly leguminous ones, with their attendant problems of grazing control, hay-and silage making and seed.production. The cereals and pulse grain crops, and the typical American crops of maize, tobacco and cotton, are naturally dealt with, but potatoes and sugar beet are the only root crops discussed, the typical British root crops-mangolds, swedes, turnips and kale-not being mentioned.

The text is always clear and straightforward, and well supplied with actual examples, tables, figures and illustrations. The great difficulty of the subject is that the general principles underlying the variations in the actual methods of growing a particular crop over an area the size of the United States are still only imperfectly understood, and this difficulty is reflected in the book; for the general principles are often only implicit in the text, so that a student unfamiliar with the conditions in the various States will sometimes have difficulty in appreciating the factors controlling the cultivations used. The value of the book is that it contains in one volume material that is either only obtainable in encyclopædias and in a mass of separate bulletins, or else is only cursorily dealt with in the elementary agricultural books. E. W. R. 